\title{
Foreign takeovers of Australian listed entities
}

\author{
By \\ Martin Bugeja* \\ University of Technology, Sydney
}

\begin{abstract}
This study examines if Australian target firm abnormal returns and characteristics differ between Australian and foreign bidders. The results indicate that takeovers from foreign bidders are associated with higher target firm abnormal returns than bids from Australian firms. Overseas bidders also pay an additional premium for research intensive target firms. Target firms that receive an offer from outside Australia are significantly larger, have lower leverage, and are more likely to operate in the resources sector. Foreign acquisitions are also more likely to be a friendly takeover. The relative exchange rate is not associated with the likelihood of a foreign takeover. There is no difference in takeover success or competition between domestic and foreign bids.
\end{abstract}

Key Words: Foreign takeovers, takeover premiums, mergers and acquisitions

JEL Classifications: G34, F21, G30

\footnotetext{
"Corresponding author: Martin Bugeja, School of Accounting, The University of Technology Sydney, 2007, New South Wales, Australia. Telephone + 6129514 3743, fax + 61295143669 .

Acknowledgements: The author wishes to acknowledge the helpful comments received from an anonymous referee and the research assistance of Raghav Jain.

E-mail address: martin.bugeja@uts.edu.au
} 


\title{
Foreign takeovers of Australian listed entities
}

\begin{abstract}
This study examines if Australian target firm abnormal returns and characteristics differ between Australian and foreign bidders. The results indicate that takeovers from foreign bidders are associated with higher target firm abnormal returns than bids from Australian firms. Overseas bidders also pay an additional premium for research intensive target firms. Target firms that receive an offer from outside Australia are significantly larger, have lower leverage, and are more likely to operate in the resources sector. Foreign acquisitions are also more likely to be a friendly takeover. The relative exchange rate is not associated with the likelihood of a foreign takeover. There is no difference in takeover success or competition between domestic and foreign bids.
\end{abstract}

Key Words: Foreign takeovers, takeover premiums, mergers and acquisitions

JEL Classifications: G34, F21, G30 


\section{Introduction}

Foreign acquisitions of Australian firms, particularly in the resources sector, are often contentious and attract substantial political and media debate. For example, in February 2009 there was significant media and political attention on the proposed investment by Aluminium Corporation of China (Chinalco) in the resource projects of Rio Tinto Limited. Commenting on the proposed investment Senator Nick Xenophon stated: "This deal is not in the national interest. You sell the milk, not the cow, and we should be selling the minerals and not the mine." ${ }^{1}$ Similarly, the decision of the Federal Treasurer to block China Nonferrous Metal Mining Group from obtaining a controlling interest in Lynas Corporation created widespread discussion. ${ }^{2}$ Despite the significant attention that this topic attracts at present there is no empirical evidence examining takeovers offers for Australian listed firms by overseas entities. This study aims to address this void in the literature by examining if the characteristics of target firms subject to a foreign takeover are different to those subject to a takeover from an Australian firm. Secondly, this paper determines whether similar to studies in the US (e.g., Harris and Ravenscraft, 1991) shareholders in Australian target firms accrue higher wealth gains when a foreign bidder makes a takeover offer.

Previous research suggests that foreign acquirers will make a cross-border takeover to obtain access to technology (Harris and Ravenscraft, 1991) and will make bids for relatively larger targets due to the greater search costs of making an overseas acquisition (Chen and $\mathrm{Su}, 1997)$. It is also suggested that that domestic firms will be more likely to receive a foreign takeover in periods of domestic currency weakness (Froot and Stein, 1991). Supporting the results in

\footnotetext{
${ }^{1}$ See "Nick Xenophon hits out at Rio Tinto sale" available at http://www.adelaidenow.com.au/news/mr-x-hitsout-at-rio-tinto-sale/story-e6freo8c-1225710562261. Created on May 9, 2009.

${ }^{2}$ See for example the media article by Marriner (2009).
} 
Chen and Su (1997) this study documents that target firms subject to a foreign takeover are relatively larger in size. Inconsistent with expectations however, we find that Australian target firms that receive a foreign bid are no more research intensive than target firms that attract a takeover from an Australian firm. The level of the Australian dollar exchange rate is insignificant in explaining the likelihood of a foreign takeover bid. The results also indicate that targets of foreign bidders have significantly lower leverage and are significantly more likely to be operating in the resources sector.

Consistent with evidence from the US (Harris and Ravenscraft, 1991; Shaked, Michel and McClain, 1991 and Cebenoyan, Papaioannou and Travlos, 1992) we document that target shareholders receive significantly higher abnormal returns in takeovers announced by foreign bidders. As this result indicates that foreign firms are willing to pay more for Australian targets than their domestic counterparts it at least partially addresses the political concern over allowing foreigners to purchase domestic assets. The results also show that target firm abnormal return in takeovers from overseas bidders are positively associated with target firm research and development (R\&D) intensity consistent with the US findings in Harris and Ravenscraft (1991). The Australian dollar exchange rate is unrelated to target shareholder wealth gains in foreign takeovers.

The remainder of this study is arranged as follows. Section 2 discusses prior literature relevant to this study and describes the regulatory framework for foreign takeovers of Australian companies. The research method is described in section 3. The data collection process is presented in section 4 , whilst section 5 provides the results of the empirical testing. The final section of the paper provides discussion and conclusion. 


\section{Prior research and regulatory framework}

\subsection{Regulation of foreign takeovers}

Foreign investment in Australia is regulated by the Foreign Acquisitions and Takeovers Act 1975. Under section 18 of the Act the Federal Treasurer can prohibit a foreign takeover or approve it subject to conditions where the acquisition is considered to be contrary to the national interest. ${ }^{3}$ Interestingly, the Act does not provide a definition of what is meant by the term national interest. ${ }^{4}$ Under the operation of the Act foreigners must currently obtain approval from the Foreign Investment Review Board (FIRB) of plans to acquire individually more than $15 \%$ of an Australian company worth equal to or more than $\$ 219$ million. $^{5}$

\subsection{Prior research}

Research across many countries documents that target shareholders earn significant positive abnormal returns around takeover announcements. For instance, Bauguess, Moeller, Schlingemann and Zutter (2009) report in the US target abnormal returns of $22 \%$ over the three day event window centred on the takeover announcement. Similar positive target shareholder abnormal returns have also been reported in Australia (e.g., Maheswaran and Pinder, 2005) and the UK (e.g., Hodgkinson and Partington, 2008). Studies however, investigating the impact of the domicile of the bidder on target shareholder wealth are restricted to the United States. Evidence from the US indicates that target shareholders of US

\footnotetext{
${ }^{3}$ The Foreign Acquisitions and Takeovers Act can be accessed at the following website: http://www.austlii.edu.au/au/legis/cth/consol_act/faata1975355/

${ }^{4}$ The lack of consistency in the application of what is in the 'national interest' has received recent criticism in the financial press. See for example, Firth (2009) and Kirchner, (2009).

${ }^{5}$ This threshold was increased from \$100 million in September 2009.
} 
domiciled targets (Harris and Ravenscraft, 1991; Shaked, Michel and McClain, 1991 and Cebenoyan, Papaioannou and Travlos, 1992) acquired by an overseas bidder earn higher abnormal returns than shareholders of targets acquired by a domestic US bidder. At present no research has compared Australian target firm abnormal returns across domestic and foreign bids.

Related research has examined the short and long run returns to acquiring firms that make overseas acquisitions. Findings from the UK (Conn, Cosh, Guest and Hughes, 2005) and US (Moeller and Schlingemann, 2005) indicate that acquiring firms earn significantly lower returns around a takeover announcement when they bid for a foreign firm compared to a takeover offer for a domestic firm. Similarly, acquirers of a foreign target have significantly lower long run post-acquisition performance than bidders that acquire a domestic target (Aw and Chaterjee, 2004; Conn, Cosh, Guest and Hughes, 2005 and Moeller and Schlingemann, 2005). Baker, Foley and Wurgler (2004) find foreign direct investment is driven by low-cost financial capital being available to firms in the source country. In contrast the valuation of assets in the host country is not related to the level of foreign direct investment. A combination of the findings above suggests that bidders access lower cost capital to overpay for foreign acquisitions.

Harris and Ravenscraft (1991) discuss that one motivation for a bidder to acquire an overseas firm is to obtain access to technologies. It is argued that R\&D often acts as a barrier to entry and it is often inefficient to transfer technologies across borders. Consistent with their expectation they find R\&D intensity is higher for targets of overseas bidders. In contrast, the results in Chen and Su (1997) show a negative relationship between R\&D intensity and the 
likelihood a firm will be subject to a takeover by a foreign firm. Harris and Ravenscraft (1991) also find that R\&D intensity is positively related to target firm abnormal returns around the takeover announcement. This relationship does not differ however between domestic and foreign targets.

Movements in the exchange rate are also expected to influence the frequency of takeover bids by foreign firms (Froot and Stein, 1991). When the domestic currency is relatively weak this lowers the cost of an acquisition for a foreign firm and makes it more affordable for them to undertake a takeover. The results in Harris and Ravenscraft (1991) show that target shareholder abnormal returns in acquisitions by foreign bidders are significantly higher when the domestic currency is weaker.

Chen and Su (1997) argue that as the search costs are larger when a firm makes a crossborder acquisition it is expected that target firms acquired by overseas bidders will be larger in size. Further, foreign acquirers will shy away from smaller firms as there is typically greater uncertainty surrounding their future prospects. Consistent with their predictions they find that targets acquired by foreign firms are of a larger size than targets acquired by domestic firms.

\section{Research method}

To determine if the characteristics of target firms subject to a takeover bid from a foreign firm differ to those subject to a takeover from an Australian entity the following logit regression model is estimated: 
OVERSEAS $_{i}=\alpha_{i}+\beta_{1}$ FCF $_{i}+\beta_{2}$ SALESGR $_{i}+\beta_{3}$ DIROWN $_{i}+\beta_{4}$ COMPBID $_{i}+\beta_{5}$ SIZE $_{i}+$ $\beta_{6} \mathrm{LEV}_{\mathrm{i}}+\beta_{7} \mathrm{MKTBK}_{\mathrm{i}}+\beta_{8} \mathrm{ROE}_{\mathrm{i}}+\beta_{9}$ TOEHOLD $_{\mathrm{i}}+\beta_{10}$ FRIENDLY $_{\mathrm{i}}+\beta_{11}$ RESOURCE $_{\mathrm{i}}$ $\beta_{12}$ RESEARCH $_{\mathrm{i}}+\beta_{13} \mathrm{EXCHRATE}_{\mathrm{i}}+\mathrm{YEAR}+\varepsilon_{\mathrm{i}}$

The dependent variable is an indicator variable denoting takeovers where the bidding firm is located outside Australia. The results in Chen and Su (1997) predict that foreign bids will be for target firms of larger size. Target firm size is measured using the natural logarithm of target market capitalisation three months prior to the takeover announcement (SIZE). Harris and Ravenscraft (1991) argue that foreign acquirers may make a cross-border takeover offer to obtain access to the research and technology of the target firm. Target firm research intensity is measured for the financial year prior to the takeover announcement as capitalised research and development divided by total assets $(R E S E A R C H)$. It is predicted this variable will have a positive coefficient. We also examine if Australian firms are more likely to be a target of an overseas takeover attempt during periods of a relatively weak Australian dollar. Similar to the approach in Harris and Ravenscraft (1991) we take the average exchange rate over our sample period and subtract from this amount the average exchange rate in the year of the takeover (EXCHRATE). This amount is then divided by the average exchange rate over the sample period. As a positive value of EXCHRATE indicates that the Australian dollar is relatively weak compared to its average over the sample period it is predicted to have a positive coefficient in the estimation of model (1). For the purposes of the analysis the Reserve Bank of Australia's trade-weighted index is used to measure changes in the value of the Australian dollar. ${ }^{6}$

\footnotetext{
${ }^{6}$ Historical data on the exchange rate between the Australian dollar and other major currencies (including the trade-weighted index) are available at the website of the Reserve Bank of Australia: http://www.rba.gov.au/Statistics.
} 
Much of the media attention on foreign acquisitions of Australian firms focuses on takeovers in the resources sector. As an examination of whether takeovers for firms involved in the resources sector are more likely to originate from outside Australia we include a dummy variable coded as one if the target firm is involved in exploring or extracting natural resources (RESOURCES). Firms are classified as resources or otherwise by reading the principal activities description in the directors' report for the year prior to the takeover announcement. If foreign firms prefer low-risk and profitable targets than it would be expected that firms subject to a takeover from overseas would have lower leverage and higher free cash flow, growth and performance. Free cash flow $(F C F)$ is calculated for the year prior to the takeover as cash flow from operations minus dividends plus proceeds from the sale of non-current assets minus purchases of non-current assets. This measure is scaled by average assets to avoid heteroskedasticity. Target firm growth and growth options are measured respectively using sales growth over the two years before the takeover announcement (SALESGR) and the target firm's market-to-book ratio measured at the financial year-end before the takeover announcement $(M K T B K)$. Leverage is measured as the target firm debt-to-equity ratio $(L E V)$ and performance as the target firm return on equity ratio $(R O E)$. Both these ratios are calculated for the financial year ending prior to the takeover announcement.

Target firm ownership structure is controlled for by including the ownership of the target firm directors $(D I R O W N)$ and toehold stake of the bidding firm in the model (TOEHOLD). To determine if there is an increased proportion of competing bids where there is a foreign bidder we include a dummy variable indicating takeovers where more than one bidder announces a simultaneous takeover for the target firm (COMPBID). The final variable included in model (1) is a dummy variable indicating whether the initial recommendation of 
the target firm is to accept the takeover offer (FRIENDLY). Due to the potential that media will pay additional attention to a foreign bid it may be the case that a foreign acquirer will be more likely to get agreement from the target board prior to announcing the takeover. As prior evidence (Rhodes-Kropf and Viswanathan, 2004 and Harford, 2005) indicates that mergers occur in waves year indicator variables are included in model (1) to control for year fixed effects.

Studies from the US indicate that target shareholders earn greater abnormal returns when the bidding firm is located overseas. To examine if this is also the case in Australia we estimate regression model (2). This model employs OLS and the dependent variable is the target firm buy-hold abnormal return (BHAR) calculated from 60 days prior to the takeover announcement until 30 days after the announcement. The main variable of interest in model (2) is a dummy variable denoting takeovers where the acquiring firm is domiciled outside Australia (OVERSEAS). The other explanatory variables included in the model are identical to those used in model (2). In addition however, we also include interaction variables between $O V E R S E A S$ and both the research intensity $(R E S * O S E A S)$ and exchange rate $\left(E X C H^{*} O S E A S\right)$ variables. These interaction variables will test if the association between research and the exchange rate and abnormal returns is different for takeovers made by a foreign bidder. Regression model (2) can be summarised as follows:

$$
\begin{aligned}
& \text { BHAR }_{\mathrm{i}}=\alpha_{\mathrm{i}}+\beta_{1} \text { OVERSEAS }_{\mathrm{i}}+\beta_{2} \text { FCF }_{\mathrm{i}}+\beta_{3} \text { SALESGR }_{\mathrm{i}}+\beta_{4} \text { DIROWN }_{\mathrm{i}}+\beta_{5} \text { COMPBID }_{\mathrm{i}}+ \\
& \beta_{6} \text { SIZE }_{\mathrm{i}}+\beta_{7} \text { LEV }_{\mathrm{i}}+\beta_{8} \text { MKTBK }_{\mathrm{i}}+\beta_{9} \text { ROE }_{\mathrm{i}}+\beta_{10} \text { TOEHOLD }_{\mathrm{i}}+\beta_{11} \text { FRIENDLY }_{\mathrm{i}}+ \\
& \beta_{12} \text { RESOURCE }_{\mathrm{i}}+\beta_{13} \text { RESEARCH }_{\mathrm{i}}+\beta_{14} \text { EXCHRATE }_{\mathrm{i}}+\beta_{15} \text { RES*OSEAS }_{\mathrm{i}}+ \\
& \beta_{16} \text { EXCH }^{*} \text { OSEAS }_{\mathrm{i}}+\text { YEAR } \varepsilon_{\mathrm{i}}
\end{aligned}
$$


From the results in Smith and Kim (1994) it is predicted that abnormal returns will be positively associated with target firm free cash flow. Abnormal returns are also expected to be greater when there are multiple bidders. The toehold interest of the bidder and the ownership of target firm directors act as controls for target firm ownership structure. Stulz (1988) argues that a higher premium must be paid when the bidder is required to purchase shares from a greater number of outside target shareholders. Consistent with this expectation Stulz, Walkling and Song (1990) find target abnormal returns are positively associated to target managerial ownership and negatively related to the acquiring firm toehold. Bugeja and Walter (1995) find similar results for toehold in Australia. The coefficients on sales growth, market-to-book, ROE and leverage will control respectively for any association between target firm growth, performance and risk and abnormal returns. Year dummy variables are also included in model (2) to control for year fixed effects on target firm abnormal returns.

Foreign domiciled firms are less likely to offer share consideration as Australian shareholders will find it more difficult to trade foreign stock. As such we first estimate models (1) and (2) using only takeovers where cash is exclusively offered as payment. Both models are then reestimated including all takeovers. In this subsequent analysis payment method is controlled for in each of the models by adding a cash payment dummy variable (CASHPAYT) indicating takeovers where payment is exclusively cash. It is expected from prior research both in Australia (Da Silva Rosa, Izan, Steinback and Walter, 2000 and Bugeja, 2005) and elsewhere (Wansley, Lane and Yang 1983; Huang and Walkling, 1987; Franks, Harris and Mayer 1988; Franks, Harris and Titman 1991; Masse, Hanrahan and Kushner, 1991 and Draper and Paudyal, 1999) that there will be positive relationship between target shareholder abnormal returns and cash consideration. 


\section{Data and descriptive statistics}

The Connect 4 Mergers and Acquisitions database was used to identify 646 takeovers announced for ASX listed firms between 1997 and 2008. For each takeover the statutory documents lodged by the bidding firm with the ASX (available on Connect 4) were examined to determine the domicile of the ultimate bidder. ${ }^{7}$ Each bidder was thus categorised as either being an Australian or foreign entity. The principal activities of each target firm were identified from the target firm annual report for the year before the takeover announcement sourced from the Aspect Huntley FinAnalysis Database. Each target was then classified as being an industrial or resources entity. It was necessary to delete 83 takeovers due to insufficient data to estimate the regression models. The final sample thus comprises 563 takeovers. The temporal distribution of the sample is shown in Table 1 partitioned into Australian and foreign bidders and then further separated into resources and industrial targets.

\section{INSERT TABLE 1 HERE}

The number of takeovers is fairly stable over the sample period, with the largest number of takeovers announced in 2006. The proportion of takeovers where the bidder is located overseas ranges from $19 \%$ in 2005 to $42 \%$ in 1997 . Across the entire sample period the percentage of takeovers with a foreign bidder is approximately $25 \%$. Foreign bidders are more likely to make a takeover offer for a firm involved in resource related activities with just fewer than $40 \%$ of foreign takeovers for a resource target compared to $26 \%$ for domestic bidders. This breakdown between the target industry sector for foreign bidders however

\footnotetext{
${ }^{7}$ For example, if a bidder is an Australian private company but is a subsidiary of a publicly listed firm outside Australia the takeover was classified as being made by a foreign bidder.
} 
varies greatly across the sample period. For instance in $200286 \%$ of foreign takeovers are for industrial targets compared to just $23 \%$ in 2008.

Table 2 provides a breakdown of the location of foreign bidders by year and industry. The four most common locations of overseas bidders are respectively the United States, United Kingdom, Canada and South Africa. It is interesting to note the US bidders are more likely to target Australian industrial firms (79\%), whilst UK (58\%) and Canadian (56\%) bidders more frequently make takeovers for targets in the resources sector.

Statutory takeover documents lodged with the ASX by the bidder and target were used to collect information on: consideration type, bidding firm toehold, the recommendation of the target firm board and target director ownership. Financial information was collected by downloading the target firm financial reports from the Aspect Huntley FinAnalysis database and then hand collecting the respective financial statement items. Share price information needed to calculate BHARs, market capitalisation and the market-to-book ratio was sourced from the Core Research Database administered by the Securities Industry Research Centre of Asia-Pacific (i.e., SIRCA). BHARs are calculated by subtracting the return on the All Ordinaries Accumulation Index from the target firm return. Brown and Warner (1985) indicate that the power of this zero-one model to identify abnormal returns is similar to the standard market model.

Panel A of Table 3 presents summary information on target shareholder abnormal returns. The results indicate that when payment form is ignored target shareholder abnormal returns 
are on average $35 \%$ and the magnitude of the returns do not differ significantly across bidder location. In contrast, when only cash takeovers are considered returns are $40 \%$ for foreign bids and $27 \%$ for takeovers from Australian bidders with the difference being statistically significant. The comparison of abnormal returns across the bidder domicile for non-cash payment forms is insignificant. This is not surprising however as the vast majority (86\%) of foreign bidders offer cash.

\section{INSERT TABLE 3 HERE}

A comparison of target firm and deal characteristics across bidder types is provided respectively in Panels $\mathrm{B}$ and $\mathrm{C}$ of Table 3 . The findings indicate there is a significant difference in target firm size across bidder domicile with targets of foreign bidders significantly larger than for Australian bidders. In comparison to takeovers made by their domestic counterparts targets of foreign bidders have lower director ownership and lower leverage. The lower level of director ownership potentially reflects the greater size of targets subject to a foreign takeover. As expected, the use of cash payment by foreign acquirers is significantly higher than by Australian bidders. Foreign takeovers are significantly more likely to be a friendly takeover and involve competing bidders. The univariate results do not indicate any significant difference in research intensity or the industry of the target between domestic and foreign acquisitions. The results also show that there is no statistical difference in the success rate of foreign and domestic takeovers. 
Table 4 presents average target firm abnormal returns separated by the domicile of the bidder. The average target shareholder return for takeovers from the USA, UK, Canada and South Africa are respectively: 39\%,26\%,22\% and 46\%. A $t$-test (not tabulated) comparing the abnormal returns across these four locations indicated no statistically significant difference. ${ }^{8}$

\section{INSERT TABLE 4 HERE}

Pearson and Spearman correlation coefficients between the variables included in the regression models are presented in Table 5. The Spearman correlation indicates that target firm BHARs are significantly higher in takeovers by an overseas acquirer. Additionally the Spearman correlation between target firm abnormal returns and target firm free cash flow is positive and significant. As expected from prior studies the use of cash payment is associated with higher abnormal returns. Overseas takeovers are positively correlated with: competing bids, target firm size, friendly takeovers, the target firm market-to-book ratio, the use of cash payment and targets in the resources sector. Target board ownership is negatively correlated with foreign takeovers. No individual correlation coefficients in Table 3 are above 0.8 suggesting that multicollinearity is unlikely to be a serious problem in the estimation of the regression models. ${ }^{9}$

\section{INSERT TABLE 5 HERE}

\footnotetext{
${ }^{8}$ A comparison of returns across other locations was not conducted due to the low number of observations for the other countries.

${ }^{9}$ Gujarati (1995), p. 335.
} 


\section{Results}

The results of estimating model (1) comparing the characteristics of targets subject to a takeover from foreign entities with those from Australian bidders is given in Table 6. The results are presented for both cash takeovers only (column 1) and using the entire sample (column 2). As predicted and confirming the results in Chen and Su (1997) larger target firms are more likely to be subject to an overseas takeover. The results also indicate that foreign firms prefer to make takeover offers for target firms with lower risk as highlighted by the significant negative coefficient on target firm leverage. Inconsistent with Harris and Ravenscraft (1991) the results indicate that research intensiveness is not related to the probability that a takeover offer will originate from overseas. Also inconsistent with predictions, the relative strength of the Australian dollar is insignificant in explaining the likelihood a takeover will be made by a foreign firm. This finding supports the results in Baker, Foley and Wurgler (2004) that a relatively cheap local asset does not drive foreign direct investment. The results also show that foreign takeovers are significantly more likely when the target firm is involved in the resources sector. An accept recommendation of the target board is positively associated with the probability of a foreign takeover suggesting that foreign acquirers are more likely to negotiate the deal with the target firm board. Target directors ownership is significantly lower in foreign takeover offers possibly reflecting that target firms subject to overseas bids are of a larger size. Foreign bids are also associated with a lower toehold interest reflecting the statutory limitation on foreign ownership without receiving approval of the FIRB. Interestingly, target firm growth and performance do not discriminate between a foreign and domestic takeover offer. ${ }^{10}$

\footnotetext{
${ }^{10}$ Significant coefficients on the year indicator variables were reported for 2001 (negative) and 2007 (positive)
} 


\section{INSERT TABLE 6 HERE}

Table 7 presents the results of estimating model (2) for respectively the cash payment sample (column 1) and the full sample (column 2). The results show that when the sample is restricted to cash payment target shareholders receive significantly higher returns when the bidder is listed overseas. This finding is similar to that reported in the US (Harris and Ravenscraft, 1991; Shaked, Michel and McClain, 1991 and Cebenoyan, Papaioannou and Travlos 1992). The interaction variable between a foreign bidder and research intensiveness is significantly positive. This result indicates that foreign acquirers will pay a higher premium for research intensive target firms than a domestic bidder. In contrast, the interaction variable between a foreign bidder and the exchange rate is insignificant.

Target shareholder abnormal returns are significantly higher for targets involved in the resources sector. ${ }^{11}$ Consistent with greater possible post-takeover performance improvements target firm return on equity is negatively related to target firm abnormal returns for the cash payment sample. Similar to the results in Smith and Kim (1994) target firm free cash flow is positively related to abnormal returns in the cash payment sub-sample. The coefficient on the exchange rate variable is negative and significant indicating that in periods when the Australian dollar is relatively weak there is a reduction in takeover premiums. This finding suggests that takeover premiums respond to changes in general economic conditions and is consistent with the result in Finn and Hodgson (2005) that takeover activity is driven by economic fundamentals. When the full sample is used target abnormal returns are

\footnotetext{
${ }^{11}$ In additional analysis an interaction variable between RESOURCE and OVERSEAS was included to assess if the significant result for resource sector targets differs by the domicile of the bidder. The interaction term was insignificant and the other results remained unchanged.
} 
significantly higher in competing bids, when cash payment if offered and when the target firm has lower leverage. The recommendation of target firm directors, target board ownership, the toehold interest of the bidder and target firm size are insignificant in explaining target shareholder returns.

\section{INSERT TABLE 7 HERE}

\section{Additional tests}

\section{Foreign takeovers and takeover competition and outcome}

As foreign takeovers of Australian entities frequently attract heightened media attention it is interesting to examine if foreign takeovers are associated with a greater level of takeover competition. Furthermore, given the greater attention on these takeovers it is possible the rate of success of foreign takeovers differs to those made by local Australian bidders. To investigate these issues the following three logit regression models are estimated:

$$
\begin{aligned}
& \text { COMPBID }_{i}=\alpha_{i}+\beta_{1} \text { OVERSEAS }_{i}+\beta_{2} \text { BHAR }_{i}+\beta_{3} \text { FCF }_{i}+\beta_{4} \text { SALESGR }_{i}+\beta_{5} \text { DIROWN }_{i}+ \\
& \beta_{6} \text { SIZE }_{i}+\beta_{7} \text { LEV }_{i}+\beta_{8} \text { MKTBK }_{i}+\beta_{9} \text { ROE }_{i}+\beta_{10} \text { TOEHOLD }_{i}+\beta_{11} \text { FRIENDLY }_{i}+ \\
& \beta_{12} \text { RESOURCE }_{i}+\beta_{13} \text { RESEARCH }_{i}+\varepsilon_{i}
\end{aligned}
$$

$$
\begin{aligned}
& \text { REVISION }_{i}=\alpha_{i}+\beta_{1} \text { OVERSEAS }_{i}+\beta_{2} \text { BHAR }_{i}+\beta_{3} \text { FCF }_{i}+\beta_{4} \text { SALESGR }_{i}+\beta_{5} \text { DIROWN }_{i}+ \\
& \beta_{6} \text { COMPBID }_{i}+\beta_{7} \text { SIZE }_{i}+\beta_{8} \text { LEV }_{i}+\beta_{9} \text { MKTBK }_{i}+\beta_{10} \text { ROE }_{i}+\beta_{11} \text { TOEHOLD }_{i}+ \\
& \beta_{12} \text { FRIENDLY }_{i}+\beta_{13} \text { RESOURCE }_{i}+\beta_{14} \text { RESEARCH }_{i}+\varepsilon_{i}
\end{aligned}
$$


OUTCOME $_{i}=\alpha_{i}+\beta_{1}$ OVERSEAS $_{i}+\beta_{2}$ BHAR $_{i}+\beta_{3}$ FCF $_{i}+\beta_{4}$ SALESGR $_{i}+\beta_{5}$ DIROWN $_{i}+$ $\beta_{6} \mathrm{COMPBID}_{\mathrm{i}}+\beta_{7} \mathrm{SIZE}_{\mathrm{i}}+\beta_{8} \mathrm{LEV}_{\mathrm{i}}+\beta_{9} \mathrm{MKTBK}_{\mathrm{i}}+\beta_{10} \mathrm{ROE}_{\mathrm{i}}+\beta_{11} \mathrm{TOEHOLD}_{\mathrm{i}}+$ $\beta_{12}$ FRIENDLY $_{\mathrm{i}}+\beta_{13}$ RESOURCE $_{\mathrm{i}}+\beta_{14}$ RESEARCH $_{\mathrm{i}}+\beta_{15}$ REVISION $_{\mathrm{i}}+\varepsilon_{\mathrm{i}}$

These three models respectively examine if foreign takeovers are associated with the frequency of competing takeovers (model 3), the probability of a revision in offer price (model 4) and the likelihood of a successful takeover (model 5). The dependent variable in model four is a binary variable coded as one if the bidder revises their offer price during the takeover period. All other variables are as defined previously.

The results of estimating the three regression models are presented in Table 8 for cash takeovers. The findings indicate that the domicile of the bidder is not associated with takeover competition, the probability of a revision in offer price or takeover outcome. The results for the control variables indicate that higher target free cash flow increases the likelihood of multiple bidders and a revision in the offer price. In contrast, higher target director ownership reduces the probability of takeover competition or an increased offer price. As would be expected a higher toehold increases the likelihood of takeover success and reduces the probability that another bidder will announce a competing bid. An accept recommendation of the target firm board reduces the chance that the bidder will revise the offer price but increases the probability that the takeover will succeed. A competing bid is positively associated with the frequency of a revision in offer price but reduces the likelihood of takeover success. An increase in the offer price raises the probability the takeover will succeed. Interestingly, the abnormal return around the announcement of the takeover is not 
associated with takeover competition, revisions in offer price or takeover outcome. ${ }^{12}$ The results for the takeover outcome model are consistent with Henry (2004) except that this study does not find a significant positive coefficient on takeover premium.

\section{INSERT TABLE 8 HERE}

\section{FIRB intervention}

The preceding analysis indicated that there was no difference in the rate of takeover success between foreign and domestic bids. For those foreign bids that failed an examination of announcements made to the ASX was conducted to determine if this was due to the intervention of the FIRB. Of the 49 foreign takeovers that failed only one was withdrawn following the intervention of the FIRB. This was the takeover announced for Woodside Petroleum Limited by Royal Dutch Shell in November 2000. ${ }^{13}$

\section{Time to complete}

To examine if foreign takeovers take longer to complete than domestic takeovers the number of days from the takeover announcement until the closing of the bid was calculated for successful and unsuccessful takeovers. In successful bids domestic takeovers were concluded on average in 107 days compared to 130 days for foreign bids. For unsuccessful takeovers

\footnotetext{
${ }^{12}$ The three models were also estimated for the entire sample of takeovers irrespective of payment method with the inclusion of the indicator variable denoting takeovers where cash was offered as payment. The conclusions drawn from each of the regressions models remained unchanged. The cash payment dummy was significant and positively associated with multiple bidders, offer price revisions and a successful takeover.

${ }^{13}$ It is obviously not possible to observe takeovers that are not announced because of the likelihood the acquisition would be banned by the FIRB.
} 
the length of time until the lapse of the bid was 98 days for Australian bids and 106 days for foreign bids. The differences in time to complete between domestic and foreign bids were statistically insignificant for both successful and unsuccessful takeovers.

\section{Exchange rate}

It had been predicted that foreign takeovers would be more likely during periods of relative weakness in the Australian dollar. The results however, indicate that the exchange rate is not associated with the likelihood of a foreign bid, nor is it related to takeover premiums. As a sensitivity test the exchange rate employed in the testing of models (1) and (2) was respecified using alternatively the Australian dollar exchange rate against the United States dollar and the Great Britain pound. Using these alternative exchange rate measures the exchange rate variable in models (1) and (2) and the exchange rate interaction term in model (2) remained insignificant. The interpretations on the other variables were unchanged.

\section{Bidding firm abnormal returns}

Table 9 presents data on bidding firm abnormal returns for two event windows around the takeover announcement: one day before until one day after and ten days before until ten days after. Share prices for Australian bidders are sourced from the Core Research Database, whilst share prices for overseas bidders are sourced from publicly available databases accessible through the internet. Panel A of the table presents results for all takeovers whilst Panel B provides the findings only for takeovers that offer exclusively cash payment. The results are similar across both panels with bidding firm abnormal returns not significantly different from zero other than for Australian bidders over the longer event window. A 
comparison of returns earned by bidders for ASX targets indicates that the returns received by domestic and foreign bidders are not statistically different from each other. ${ }^{14}$

\section{INSERT TABLE 9 HERE}

\section{Conclusions}

Foreign acquisitions of Australian corporations are an issue that often attracts heightened media and political attention and debate. Prior to this study there was no evidence as to the type of Australian firms that were more likely to attract a foreign takeover offer. The findings of this study indicate that Australian firms subject to a foreign takeover are typically larger, have lower leverage and are operating in the resources sector. Foreign takeovers are also more frequently friendly acquisitions. Fluctuations in the Australian dollar exchange rate and target firm research intensiveness are not related to the likelihood of a foreign takeover.

This study also investigated differences in target shareholder abnormal returns between Australian and overseas bidders. Consistent with previous studies from the US, target shareholders earn significantly higher abnormal returns when the bidder is located outside Australia. This result indicates that political concerns over the selling of Australia assets to foreigners cannot be justified in regards to the price that is paid. Furthermore, the findings

\footnotetext{
${ }^{14}$ The sample size for Australian bidders is lower than the number of takeovers as some domestic bidders are not listed. Eight of the foreign bidders were not listed whilst share prices could not be obtained for a further 28 firms.
} 
show that overseas acquirers pay an additional premium for research intensive targets in comparison to Australian bidders. In contrast, target abnormal returns of overseas bidders are not explained by exchange rate fluctuations. The results also signify that target firms in the resources sector earn higher abnormal returns. As an extension of this study it would be interesting for future research to examine the performance of Australian entities acquiring targets outside Australia. 


\section{References}

Aw, M., and R. Chatterjee, 2004, The performance of UK firms acquiring large cross-border and domestic takeover targets, Applied Financial Economics 14, pp. 337-349.

Baker, M., C. Foley and J. Wurgler, 2004, Multinationals as arbitrageurs: The effect of stock market valuations on foreign direct investment, Working paper, New York University.

Bauguess, S., S. Moeller, F. Schlingemann and C. Zutter, Ownership structure and target returns, Journal of Corporate Finance 15, 48-65.

Brown, S., and J. Warner, 1985, Using daily stock returns: The case of event studies, Journal of Financial Economics 14, 3-31.

Bugeja, M., 2005, The effect of independent expert reports in Australian takeovers, Accounting and Finance 45, 519-536.

Bugeja, M., and T. Walter, 1995, An empirical analysis of some determinants of the target shareholder premium in takeovers, Accounting and Finance 35, 33-60.

Cebenoyan, A., G. Papaioannou, and N. Travlos, 1992, Foreign takeover wealth activity in the US and wealth effects for target firm shareholders, Financial Management 21, 58-68.

Chen C., and R. Su, 1997, Do cross-border acquisitions of US targets differ from US domestic takeover targets? Global Finance Journal 8, 71-82.

Conn, R., A. Cosh, P. Guest, and A. Hughes, 2005, The impact on UK acquirers of domestic, cross-border, public and private acquisitions, Journal of Business, Finance and Accounting $32,815-870$. 
Da Silva Rosa, R., H. Izan, A. Steinback, and T. Walter, 2000, The method of payment decision in Australian takeovers: An investigation of causes and consequences, Australian Journal of Management 25, 67-94.

Draper, P. and K. Paudyal, 1999, Corporate takeovers: Mode of payment, returns and trading activity, Journal of Business, Finance and Accounting 26, 521-558.

Finn, F. And A. Hodgson, 2005, Takeover activity in Australia: endogenous and exogenous influences, Accounting and Finance 45, 375-394.

Firth, B., 2009, FIRB flouting investment law, The Australian, 6 October 2009, 22.

Franks, J., R. Harris, and C. Mayer, 1988, Means of payment in takeovers: Results in the United Kingdom and the United States, in AJ Auerbach (ed.), Corporate Takeovers: Causes and Consequences, (University of Chicago Press), 221-264.

Franks, J., R. Harris, and S. Titman, 1991, The postmerger share-price performance of acquiring firms, Journal of Financial Economics 29, 81-96.

Froot, K., and J., Stein, 1991, Exchange rates and foreign direct investment: An imperfect capital markets approach, Quarterly Journal of Economics 106, 1191-1217.

Gujarati, D., 1995, Basic Econometrics (3 ${ }^{\text {rd }}$ ed.), (Sydney: McGraw-Hill).

Harford, J, 2005, What drives merger waves? Journal of Financial Economics 77, 529-560.

Harris, R., and D. Ravenscraft, 1991, The role of acquisitions in foreign direct investment: Evidence from the US stock market, Journal of Finance 46, 825-844.

Henry, D., 2004, Corporate governance and ownership structure of target companies and the outcome of takeovers, Pacific-Basin Finance Journal 12, 419-444. 
Hodgkinson, L., and G. Partington, 2008, The motivation for takeovers in the UK, Journal of Business, Finance and Accounting 35, 102-126.

Huang, Y., and R. Walkling, 1987, Target abnormal returns associated with acquisition announcements: Payment acquisition form, and managerial resistance, Journal of Financial Economics 19, 329-349.

Kirchner, S, 2009, Canberra's Investment Confusion, The Asian Wall Street Journal, 30 September 2009, 13.

Maheswaran, K., and S. Pinder, Australian evidence on the determinants and impact of takeover resistance, Accounting and Finance 45, 613-633.

Marriner, C., 2009, 'Racist' FIRB a handbrake on growth, says miner, The Age, September $30,2009,1$.

Masse, I., Hanrahan, R. and J. Kushner, 1991, The effect of the method of payment on stock returns in Canadian tender offers and merger proposals for both target and bidding firms, Quarterly Journal of Business 29, 102-124.

Moeller, S., and F. Schlingemann, 2005, Global diversification and bidder gains: A comparison between cross-border and domestic acquisitions, Journal of Banking and Finance 29, 533-564.

Rhodes-Kropf, M. and S. Viswanathan, 2004, Market valuation and merger waves, Journal of Finance 59, 2685-2718.

Shaked, I., A. Michel, and D. McClain, 1991, The foreign acquirer bonanza: Myth or reality, Journal of Business, Finance and Accounting 18, 431-447. 
Smith, R. and J. Kim, 1994, The combined effects of free cash flow and financial slack on bidder and target stock returns, Journal of Business 67, 281-310.

Stulz, R., 1988, Managerial control of voting rights: Financing policies and the market for corporate control, Journal of Financial Economics 20, 25-54.

Stulz, R., R. Walkling, and M. Song, 1990, The distribution of target ownership and the division of gains in successful takeovers, Journal of Finance 45, 817-833.

Wansley, J., W. Lane, Wand H. Yang, 1983, Abnormal returns to acquired firms by type of acquisition and method of payment, Financial Management 12, 16-22. 
Table 1

\section{Distribution of takeover offers across Australian and foreign bidders}

This table shows the number of takeovers for ASX listed firms between 1997 and 2008. Each takeover is classified according to whether the ultimate bidder is domiciled within or outside Australia and whether the target firm has activities in the resources sector.

\begin{tabular}{|c|c|c|c|c|c|c|c|}
\hline & $\begin{array}{c}\text { Aust bidder } \\
\text { resources } \\
\text { target }\end{array}$ & $\begin{array}{c}\text { Aust bidder } \\
\text { industrial } \\
\text { target }\end{array}$ & Sub-total & $\begin{array}{c}\text { O/seas bidder } \\
\text { resources } \\
\text { target }\end{array}$ & $\begin{array}{c}\mathrm{O} / \text { seas bidder } \\
\text { industrial } \\
\text { target }\end{array}$ & Sub-total & Total \\
\hline \multirow[t]{2}{*}{1997} & 9 & 16 & 25 & 3 & 15 & 18 & 43 \\
\hline & $36.00 \%$ & $64.00 \%$ & $58.14 \%$ & $16.67 \%$ & $83.33 \%$ & $41.86 \%$ & \\
\hline \multirow[t]{2}{*}{1998} & 12 & 22 & 34 & 4 & 6 & 10 & 44 \\
\hline & $35.29 \%$ & $64.71 \%$ & $77.27 \%$ & $40.00 \%$ & $60.00 \%$ & $22.73 \%$ & \\
\hline \multirow[t]{2}{*}{1999} & 9 & 26 & 35 & 3 & 6 & 9 & 44 \\
\hline & $25.71 \%$ & $74.29 \%$ & $79.55 \%$ & $33.33 \%$ & $66.67 \%$ & $20.45 \%$ & \\
\hline \multirow[t]{2}{*}{2000} & 13 & 30 & 43 & 9 & 4 & 13 & 56 \\
\hline & $30.23 \%$ & $69.77 \%$ & $76.79 \%$ & $69.23 \%$ & $30.77 \%$ & $23.21 \%$ & \\
\hline \multirow[t]{2}{*}{2001} & 8 & 30 & 38 & 2 & 8 & 10 & 48 \\
\hline & $21.05 \%$ & $78.95 \%$ & $79.17 \%$ & $20.00 \%$ & $80.00 \%$ & $20.83 \%$ & \\
\hline \multirow[t]{2}{*}{2002} & 4 & 23 & 27 & 1 & 6 & 7 & 34 \\
\hline & $14.81 \%$ & $85.19 \%$ & $79.41 \%$ & $14.29 \%$ & $85.71 \%$ & $20.59 \%$ & \\
\hline \multirow[t]{2}{*}{2003} & 3 & 31 & 34 & 2 & 8 & 10 & 44 \\
\hline & $8.82 \%$ & $91.18 \%$ & $77.27 \%$ & $20.00 \%$ & $80.00 \%$ & $22.73 \%$ & \\
\hline \multirow[t]{2}{*}{2004} & 5 & 25 & 30 & 2 & 6 & 8 & 38 \\
\hline & $16.67 \%$ & $83.33 \%$ & $78.95 \%$ & $25.00 \%$ & $75.00 \%$ & $21.05 \%$ & \\
\hline \multirow[t]{2}{*}{2005} & 5 & 25 & 30 & 5 & 2 & 7 & 37 \\
\hline & $16.67 \%$ & $83.33 \%$ & $81.08 \%$ & $71.43 \%$ & $28.57 \%$ & $18.92 \%$ & \\
\hline \multirow[t]{2}{*}{2006} & 16 & 37 & 53 & 4 & 10 & 14 & 67 \\
\hline & $30.19 \%$ & $69.81 \%$ & $79.10 \%$ & $28.57 \%$ & $71.43 \%$ & $20.90 \%$ & \\
\hline \multirow[t]{2}{*}{2007} & 16 & 25 & 41 & 10 & 11 & 21 & 62 \\
\hline & $39.02 \%$ & $60.98 \%$ & $66.13 \%$ & $47.62 \%$ & $52.38 \%$ & $33.87 \%$ & \\
\hline \multirow[t]{2}{*}{2008} & 12 & 21 & 33 & 10 & 3 & 13 & 46 \\
\hline & $36.36 \%$ & $63.64 \%$ & $71.74 \%$ & $76.92 \%$ & $23.08 \%$ & $28.26 \%$ & \\
\hline \multirow[t]{2}{*}{ Total } & 112 & 311 & 423 & 55 & 85 & 140 & 563 \\
\hline & $26.48 \%$ & $73.52 \%$ & $75.13 \%$ & $39.29 \%$ & $60.71 \%$ & $24.87 \%$ & \\
\hline
\end{tabular}




\section{Table 2}

\section{Domicile of foreign bidders}

This table presents information across the sample period on the domicile of foreign bidders for ASX listed targets classified into resources (R) and industrial (I) targets.

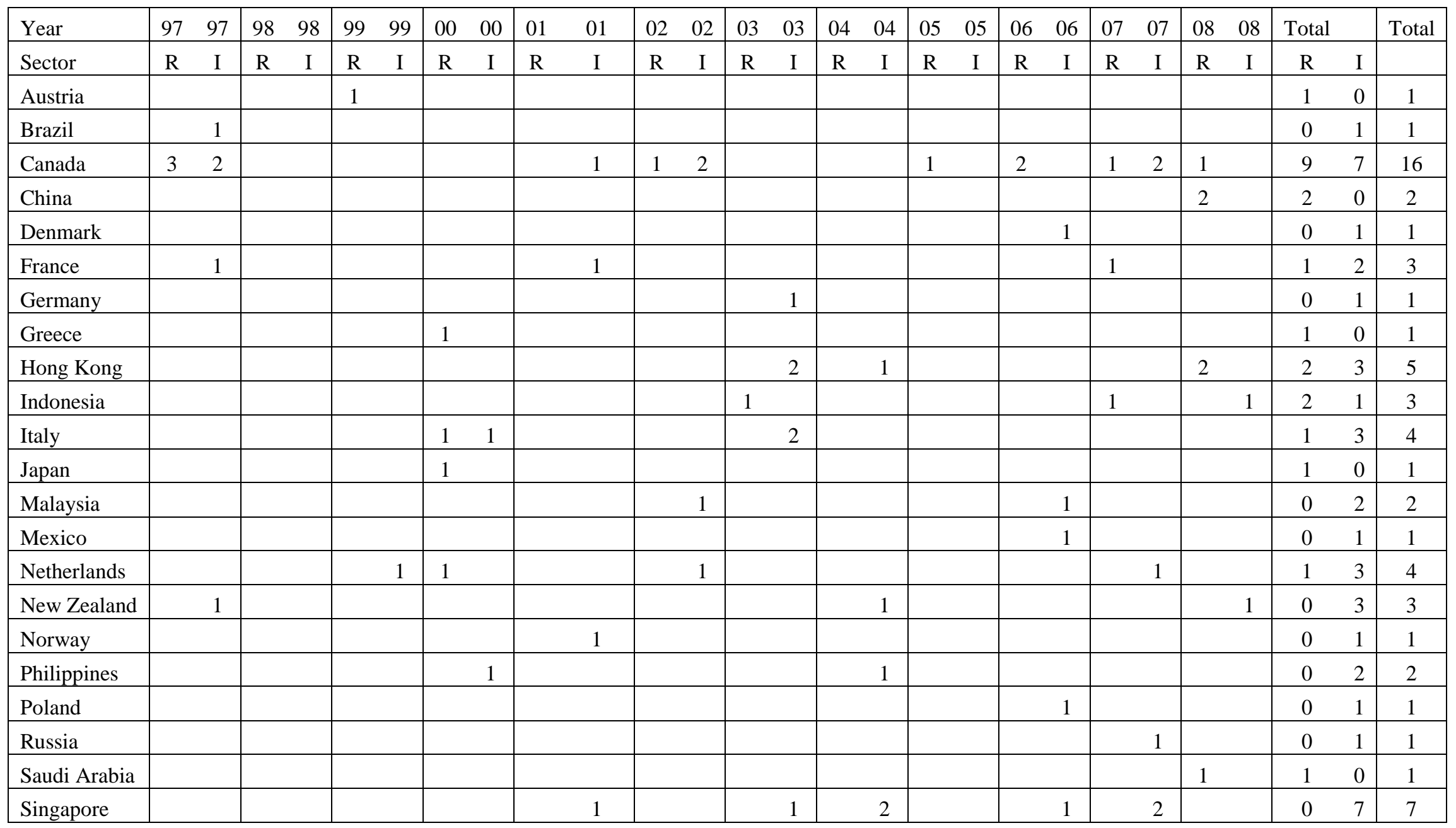


Table 2

Domicile of foreign bidders - continued

\begin{tabular}{|c|c|c|c|c|c|c|c|c|c|c|c|c|c|c|c|c|c|c|c|c|c|c|c|c|c|c|c|}
\hline Year & 97 & 97 & 98 & 98 & 99 & 99 & 00 & 00 & 01 & 01 & 02 & 02 & 03 & 03 & 04 & 04 & 05 & 05 & 06 & 06 & 07 & 07 & 08 & 08 & Total & & Total \\
\hline Sector & $\mathrm{R}$ & $\mathrm{I}$ & $\mathrm{R}$ & $\mathrm{I}$ & $\mathrm{R}$ & I & $\mathrm{R}$ & I & $\mathrm{R}$ & $\mathrm{I}$ & $\mathrm{R}$ & $\mathrm{I}$ & $\mathrm{R}$ & $\mathrm{I}$ & $\mathrm{R}$ & $\mathrm{I}$ & $\mathrm{R}$ & $\mathrm{I}$ & $\mathrm{R}$ & $\mathrm{I}$ & $\mathrm{R}$ & $\mathrm{I}$ & $\mathrm{R}$ & $\mathrm{I}$ & $\mathrm{R}$ & I & \\
\hline South Africa & & 4 & & 2 & 1 & & 2 & & 1 & & & & 1 & & 1 & 1 & & & & 1 & & & & & 6 & 8 & 14 \\
\hline Spain & & & 1 & & & & & & & & & & & & & & & 1 & & & & & & & 1 & 1 & 2 \\
\hline Sweden & & & & & & & & & & & & & & & & & & & & 1 & & & & & 0 & 1 & 1 \\
\hline Switzerland & & & & & & & & & & & & & & & & & & & & & 3 & & 1 & & 4 & 0 & 4 \\
\hline UK & & 1 & 2 & 1 & 1 & 3 & 1 & 1 & & 1 & & & & 1 & 1 & & 3 & & 2 & & 3 & 2 & 2 & 1 & 15 & 11 & 26 \\
\hline Ukraine & & & & & & & & & & & & & & & & & & & & & 1 & & & & 1 & 0 & 1 \\
\hline USA & & 5 & 1 & 3 & & 2 & 2 & 1 & 1 & 3 & & 2 & & 1 & & & 1 & 1 & & 3 & & 2 & 1 & & 6 & 23 & 29 \\
\hline Vietnam & & & & & & & & & & & & & & & & & & & & & & 1 & & & 0 & 1 & 1 \\
\hline Total & 3 & 15 & 4 & 6 & 3 & 6 & 9 & 4 & 2 & 8 & 1 & 6 & 2 & 8 & 2 & 6 & 5 & 2 & 4 & 10 & 10 & 11 & 10 & 3 & 55 & 85 & 140 \\
\hline
\end{tabular}




\section{Table 3}

\section{Takeover premiums and target firm and deal characteristics by bidder type}

This table presents means for takeover premiums, target firm characteristics and deal characteristics partitioned by the domicile of the bidder. Takeover premiums are calculated as the BHAR from 60 days prior to the takeover announcement until 30 days after. Target firm characteristics include: free cash flow $(F C F)$ sales growth in the two years prior to the takeover (SALESGR), target director ownership (DIROWN), capitalised research as a percentage of total assets $(R E S E A R C H)$, the natural logarithm of market capitalisation (SIZE), debt-to-equity ratio $(L E V)$, market-to-book ratio $(M K T B K)$ return on equity ratio $(R O E)$ and a dummy variable indicating if the target firm is in the resources sector (RESOURCE). Deal characteristics are: the ownership interest of the bidding firm in the target at the announcement of the takeover (TOEHOLD), a measure of fluctuations in the Australian dollar exchange rate (EXCHRATE) and dummy variables indicating takeovers where: the target board recommends takeover acceptance (FRIENDLY), a competing takeover exists (COMPBID) and the consideration offered is exclusively cash (CASHPAYT). The table also reports the percentage of takeovers with a successful outcome (OUTCOME). A univariate test of differences in means between foreign and Australian bids is presented. For continuous/(binary) variables a $t$-test/( $\chi^{2}$-test) is used to assess if the difference in means is statistically significant.

\begin{tabular}{|c|c|c|c|c|}
\hline & $\begin{array}{c}\text { Australian } \\
\text { bidders }\end{array}$ & $\begin{array}{l}\text { Foreign } \\
\text { bidders }\end{array}$ & Overall & $\begin{array}{c}\text { Test of difference } \\
\text { Australian vs } \\
\text { Foreign }\end{array}$ \\
\hline \multicolumn{5}{|l|}{$\begin{array}{l}\text { Panel A: Takeover } \\
\text { premiums }\end{array}$} \\
\hline All takeovers & 35.23 & 35.07 & 35.19 & 0.01 \\
\hline Cash payment only & 27.01 & 40.04 & 31.41 & $-2.83 * * *$ \\
\hline Other payment forms & 51.57 & 5.28 & 41.68 & 1.51 \\
\hline \multicolumn{5}{|l|}{$\begin{array}{l}\text { Panel B: Target } \\
\text { firm characteristics }\end{array}$} \\
\hline$F C F$ & -9.64 & -7.40 & -9.08 & -0.09 \\
\hline SALESGR & 40.36 & 31.60 & 38.19 & 0.58 \\
\hline DIROWN & 12.05 & 6.95 & 10.79 & $3.61 * * *$ \\
\hline RESEARCH & 0.75 & 1.04 & 0.83 & -0.49 \\
\hline$S I Z E$ & 17.91 & 18.85 & 18.14 & $-5.24 * * *$ \\
\hline$L E V$ & 1.15 & 0.83 & 1.07 & $2.97 * * *$ \\
\hline$M K T B K$ & 3.50 & 2.28 & 3.20 & 1.43 \\
\hline$R O E$ & -1.25 & -0.01 & -0.93 & -1.09 \\
\hline RESOURCE & 29.56 & 32.14 & 29.55 & -0.58 \\
\hline \multicolumn{5}{|l|}{$\begin{array}{l}\text { Panel C: Deal } \\
\text { characteristics }\end{array}$} \\
\hline TOEHOLD & 20.17 & 17.13 & 19.41 & 1.14 \\
\hline FRIENDLY & 54.37 & 63.57 & 56.67 & $-1.90 *$ \\
\hline COMPBID & 21.04 & 30.71 & 23.45 & $-2.34 * *$ \\
\hline EXCHRATE & -0.01 & -0.02 & -0.01 & 1.14 \\
\hline CASHPAYT & 55.79 & 85.71 & 63.23 & $-6.36 * * *$ \\
\hline OUTCOME & 65.48 & 65.71 & 65.54 & -0.05 \\
\hline
\end{tabular}




\section{Table 4}

\section{Takeover premiums by domicile of bidders}

This table reports takeover premiums by the domicile of the bidder. Takeover premiums are calculated as the BHAR from 60 days prior to the takeover announcement until 30 days after.

\begin{tabular}{|c|c|c|c|c|c|}
\hline Country & $\begin{array}{c}\text { No of } \\
\text { takeovers }\end{array}$ & Premium & Country & $\begin{array}{c}\text { No of } \\
\text { takeovers }\end{array}$ & Premium \\
\hline Austria & 1 & $54.84 \%$ & $\begin{array}{c}\text { New } \\
\text { Zealand }\end{array}$ & 3 & $13.32 \%$ \\
\hline Brazil & 1 & $29.86 \%$ & Norway & 1 & $37.25 \%$ \\
\hline Canada & 16 & $21.63 \%$ & Philippines & 2 & $60.94 \%$ \\
\hline China & 2 & $54.67 \%$ & Poland & 1 & $23.26 \%$ \\
\hline Denmark & 1 & $35.29 \%$ & Russia & 1 & $109.60 \%$ \\
\hline France & 3 & $32.02 \%$ & $\begin{array}{l}\text { Saudi } \\
\text { Arabia }\end{array}$ & 1 & $31.23 \%$ \\
\hline Germany & 1 & $21.92 \%$ & Singapore & 7 & $43.56 \%$ \\
\hline Greece & 1 & $33.11 \%$ & $\begin{array}{l}\text { South } \\
\text { Africa }\end{array}$ & 14 & $46.40 \%$ \\
\hline Hong Kong & 5 & $19.92 \%$ & Spain & 2 & $5.37 \%$ \\
\hline Indonesia & 3 & $71.65 \%$ & Sweden & 1 & $34.79 \%$ \\
\hline Italy & 4 & $48.78 \%$ & Switzerland & 4 & $36.60 \%$ \\
\hline Japan & 1 & $103.09 \%$ & UK & 26 & $25.81 \%$ \\
\hline Malaysia & 2 & $40.20 \%$ & Ukraine & 1 & $45.89 \%$ \\
\hline Mexico & 1 & $29.63 \%$ & USA & 29 & $38.81 \%$ \\
\hline Netherlands & 4 & $22.00 \%$ & Vietnam & 1 & $10.01 \%$ \\
\hline
\end{tabular}


Table 5

Correlation between dependent and independent variables

Pearson correlations are above the diagonal and Spearman correlations are below

This table presents correlation coefficients between the dependent and independent variables in the two regression models. BHARs are calculated from 60 days prior to the takeover announcement until 30 days after $(B H A R)$. Target firm characteristics include: free cash flow $(F C F)$ sales growth in the two years prior to the takeover (SALESGR), target director ownership $(D I R O W N)$, capitalised research as a percentage of total assets (RESEARCH), the natural logarithm of market capitalisation (SIZE), debt-to-equity ratio $(L E V)$, market-to-book ratio $(M K T B K)$ return on equity ratio $(R O E)$ and a dummy variable indicating if the target firm is in the resources sector $(R E S O U R C E)$. Deal characteristics are the ownership interest of the bidding firm in the target at the announcement of the takeover (TOEHOLD), a measure of fluctuations in the Australian dollar exchange rate (EXCHRATE) and dummy variables indicating takeovers where: the target board recommends takeover acceptance (FRIENDLY), whether a competing takeover exists (COMPBID) and if the consideration offered is exclusively cash (CASHPAYT). Interaction variables between $O V E R S E A S$ and $R E S E A R C H(R E S * O S E A S)$ and OVERSEAS and EXCHRATE (EXCH*OSEAS) are included.

\begin{tabular}{|c|c|c|c|c|c|c|c|c|}
\hline & $B H A R$ & OVERSEAS & $F C F$ & SALESGR & DIROWN & COMPBID & $S I Z E$ & $L E V$ \\
\hline BHAR & 1 & 0.007 & 0.009 & -0.010 & -0.030 & 0.002 & -0.013 & -0.014 \\
\hline OVERSEAS & $0.164 * * *$ & 1 & 0.027 & -0.034 & $-0.129 * * *$ & $0.099 * *$ & $0.206 * * *$ & 0.066 \\
\hline$F C F$ & $0.197 * * *$ & $0.070 *$ & 1 & -0.069 & -0.003 & 0.018 & $0.236 * * *$ & -0.003 \\
\hline SALESGR & -0.030 & $0.073 *$ & 0.068 & 1 & -0.033 & -0.033 & -0.011 & -0.004 \\
\hline DIROWN & 0.037 & $-0.120 * * *$ & -0.042 & $0.069 *$ & 1 & $-0.171 * * *$ & $-0.253 * * *$ & $0.076 *$ \\
\hline COMPBID & $0.120 * * *$ & $0.099 * *$ & $0.077 *$ & -0.026 & $-0.182 * * *$ & 1 & $0.076 *$ & -0.027 \\
\hline$S I Z E$ & $0.088 * *$ & $0.215 * * *$ & $0.298 * * *$ & $0.069 *$ & $-0.340 * * *$ & $0.084 * *$ & 1 & -0.041 \\
\hline$L E V$ & 0.027 & $-0.076^{*}$ & $0.221 * * *$ & -0.048 & -0.006 & 0.034 & $0.102 * * *$ & 1 \\
\hline$M K T B K$ & -0.036 & $0.079 *$ & -0.042 & 0.061 & -0.028 & -0.001 & $0.298 * * *$ & $0.135^{* * *} *$ \\
\hline$R O E$ & -0.027 & 0.032 & $0.384 * * *$ & 0.040 & $-0.070 *$ & $-0.079 *$ & $0.367 * * *$ & $0.081 *$ \\
\hline TOEHOLD & 0.026 & -0.048 & $0.070 *$ & -0.005 & -0.004 & $-0.141 * * *$ & -0.059 & $0.155 * * *$ \\
\hline FRIENDLY & 0.055 & $0.080 *$ & 0.044 & 0.043 & $0.157 * * *$ & $-0.091 * *$ & 0.013 & $0.073^{*}$ \\
\hline RESOURCE & $0.114 * * *$ & $0.121 * * *$ & 0.046 & $-0.070 *$ & $-0.078 *$ & 0.063 & 0.062 & $-0.246 * * *$ \\
\hline RESEARCH & -0.013 & 0.050 & -0.011 & 0.027 & $0.087 * *$ & 0.024 & -0.042 & 0.067 \\
\hline EXCHRATE & 0.062 & -0.052 & 0.021 & $-0.102 * *$ & $-0.166 * * *$ & 0.049 & $0.157 * * *$ & -0.048 \\
\hline CASHPAYT & $0.220 * * *$ & $0.268 * * *$ & $0.192 * * *$ & 0.019 & 0.003 & $0.074 *$ & 0.017 & $0.093 *$ \\
\hline$O S E A S * R E S$ & 0.057 & $0.325 * * *$ & 0.012 & $0.100 * * *$ & 0.038 & 0.037 & 0.042 & -0.018 \\
\hline OSEAS*EXCH & 0.031 & $-0.155 * * *$ & $0.102 * *$ & -0.021 & -0.068 & -0.021 & -0.046 & $-0.072 *$ \\
\hline
\end{tabular}

$* * *$ Significant at the $1 \%$ level $* *$ Significant at the $5 \%$ level * Significant at the $10 \%$ level 
Table 5 - continued

\begin{tabular}{|c|c|c|c|c|c|c|c|c|c|c|}
\hline & $M K T B K$ & $R O E$ & $\begin{array}{c}\text { TOE } \\
\text { HOLD }\end{array}$ & $\begin{array}{c}\text { FRIENDL } \\
Y \\
\end{array}$ & $\begin{array}{c}\text { RESOURC } \\
E\end{array}$ & $\begin{array}{c}\text { RESEAR } \\
C H\end{array}$ & $\begin{array}{l}E X C H \\
R A T E\end{array}$ & $\begin{array}{l}\text { CASH } \\
P A Y T\end{array}$ & $\begin{array}{c}O S E A S^{*} \\
R E S\end{array}$ & $\begin{array}{c}\text { OSEAS* } \\
\text { EXCH }\end{array}$ \\
\hline BHAR & -0.003 & 0.005 & -0.027 & 0.041 & $0.091 * *$ & 0.010 & -0.052 & -0.024 & 0.032 & 0.006 \\
\hline OVERSEAS & $0.125 * * *$ & 0.024 & -0.037 & $0.080^{*}$ & $0.121 * * *$ & 0.025 & -0.048 & $0.268 * * *$ & $0.139 * * *$ & $-0.180 * * *$ \\
\hline$F C F$ & 0.052 & 0.010 & 0.052 & 0.025 & -0.013 & -0.001 & -0.007 & $0.135 * * *$ & 0.012 & 0.067 \\
\hline SALESGR & -0.004 & -0.014 & 0.002 & $-0.076^{*}$ & -0.041 & -0.010 & -0.006 & -0.039 & -0.006 & 0.003 \\
\hline DIROWN & 0.014 & $-0.080^{*}$ & 0.030 & $0.183 * * *$ & $-0.159 * * *$ & $0.074 *$ & $-0.111 * * *$ & 0.052 & 0.067 & 0.007 \\
\hline COMPBID & $0.072 *$ & 0.021 & $-0.119 * * *$ & $-0.091 * *$ & 0.063 & -0.025 & 0.053 & $0.074 *$ & 0.013 & -0.037 \\
\hline$S I Z E$ & $0.072 *$ & 0.065 & -0.021 & 0.023 & $0.072 *$ & -0.049 & $-0.128 * * *$ & -0.009 & -0.021 & $-0.079 *$ \\
\hline$L E V$ & $0.568 * * *$ & $-0.082 *$ & -0.020 & -0.043 & -0.028 & -0.009 & -0.057 & -0.058 & -0.005 & $-0.122 * * *$ \\
\hline$M K T B K$ & 1 & -0.023 & -0.037 & 0.016 & 0.008 & -0.013 & $-0.101 * *$ & 0.005 & -0.007 & $-0.207 * * *$ \\
\hline$R O E$ & $0.094 * *$ & 1 & 0.022 & -0.033 & -0.060 & 0.006 & 0.060 & 0.061 & 0.004 & -0.004 \\
\hline TOEHOLD & -0.037 & 0.033 & 1 & $0.079 *$ & $-0.080 *$ & -0.047 & 0.062 & $0.156 * * *$ & -0.016 & -0.058 \\
\hline FRIENDLY & 0.002 & $0.072 *$ & $0.152 * * *$ & 1 & $-0.115 * * *$ & 0.005 & -0.044 & 0.024 & 0.049 & -0.012 \\
\hline RESOURCE & $0.220 * * *$ & $-0.143 * * *$ & $-0.099 * *$ & $-0.115 * * *$ & 1 & $-0.072 *$ & $-0.110 * * *$ & $-0.158 * * *$ & -0.051 & $-0.101 * *$ \\
\hline RESEARCH & -0.067 & 0.039 & $-0.083 * *$ & 0.063 & $-0.142 * * *$ & 1 & 0.014 & 0.068 & $0.630 * * *$ & 0.040 \\
\hline EXCHRATE & $-0.282 * * *$ & -0.065 & 0.024 & 0.045 & $-0.124 * * *$ & 0.024 & 1 & 0.026 & 0.004 & $0.479 * * *$ \\
\hline CASHPAYT & $-0.122 * * *$ & 0.067 & $0.249 * * *$ & 0.024 & $-0.158 * * *$ & $0.078 *$ & 0.035 & 1 & 0.048 & $-0.080 *$ \\
\hline OSEASRES & -0.052 & 0.048 & -0.045 & 0.065 & -0.059 & $0.535 * * *$ & 0.009 & $0.081 *$ & 1 & 0.044 \\
\hline OSASEXCH & $-0.120 * * *$ & -0.003 & $-0.093 * *$ & -0.017 & -0.064 & 0.016 & $0.424 * * *$ & -0.067 & -0.007 & 1 \\
\hline
\end{tabular}


Table 6

\section{Logit model testing for differences in target firm characteristics between foreign bidders and Australian bidders}

The dependent variable is an indicator variable denoting takeovers where the bidder is domiciled outside Australia. The independent variables are target firm: free cash flow $(F C F)$, sales growth in the two years prior to the takeover (SALESGR), director ownership $(D I R O W N)$ capitalised research as a percentage of total assets (RESEARCH), size measured using the natural logarithm of market capitalisation (SIZE), debt-to-equity ratio $(L E V)$, market-to-book ratio $(M K T B K)$ return on equity ratio $(R O E)$ and a dummy variable indicating if the target firm is in the resources sector (RESOURCE). The model also includes dummy variables indicating: a competing takeover exists for the target firm (COMPBID), whether the consideration offered is entirely cash (CASHPAYT) and whether the initial recommendation of the target board is acceptance of the takeover (FRIENDLY). The model also includes the relative value of the Australian dollar over the sample period (EXCHRATE) and the ownership interest of the bidder at the time the takeover is announced (TOEHOLD). Year indicator variables are also included in the model but results are not reported.

\begin{tabular}{|c|c|c|}
\hline & $\begin{array}{c}\text { Cash offers } \\
\text { (1) }\end{array}$ & $\begin{array}{c}\text { All payment methods } \\
\text { (2) }\end{array}$ \\
\hline \multirow[t]{2}{*}{ Intercept } & -9.8808 & -11.4030 \\
\hline & $(-0.01)$ & $(-0.01)$ \\
\hline \multirow[t]{2}{*}{$F C F$} & 0.2478 & -0.3448 \\
\hline & $(0.43)$ & $(-0.72)$ \\
\hline \multirow[t]{2}{*}{ SALESGR } & -0.0058 & -0.0069 \\
\hline & $(-0.29)$ & $(-0.37)$ \\
\hline \multirow[t]{2}{*}{ DIROWN } & -1.7463 & -1.7047 \\
\hline & $(-1.90)^{*}$ & $(-1.97)^{*}$ \\
\hline \multirow[t]{2}{*}{ COMPBID } & 0.3506 & 0.03354 \\
\hline & (1.12) & $(1.23)$ \\
\hline \multirow[t]{2}{*}{ SIZE } & 0.3265 & 0.3171 \\
\hline & $(3.79) * * *$ & $(4.44) * * *$ \\
\hline \multirow[t]{2}{*}{$L E V$} & -0.1897 & -0.0414 \\
\hline & $(-1.69)^{*}$ & $(0.93)$ \\
\hline \multirow[t]{2}{*}{$M K T B K$} & 0.0551 & 0.0224 \\
\hline & (1.16) & (1.04) \\
\hline \multirow[t]{2}{*}{$R O E$} & -0.0963 & -0.0040 \\
\hline & $(-0.84)$ & $(-0.34)$ \\
\hline \multirow[t]{2}{*}{ TOEHOLD } & -1.2349 & -1.1165 \\
\hline & $(-1.94)^{*}$ & $(-1.92)^{*}$ \\
\hline \multirow[t]{2}{*}{ FRIENDLY } & 0.9395 & 0.7784 \\
\hline & $(3.26) * * *$ & $(3.15)^{* * *}$ \\
\hline \multirow[t]{2}{*}{ RESOURCE } & 0.9316 & 0.7606 \\
\hline & $(2.79) * * *$ & $(2.89) * * *$ \\
\hline \multirow[t]{2}{*}{ RESEARCH } & 1.2073 & 1.6355 \\
\hline & $(0.60)$ & $(0.86)$ \\
\hline \multirow[t]{2}{*}{ EXCHRATE } & -0.4779 & -0.4196 \\
\hline & $(-0.53)$ & $(-0.42)$ \\
\hline \multirow[t]{2}{*}{ CASHPAYT } & - & 1.9778 \\
\hline & & $(6.58) * * *$ \\
\hline$Y E A R$ & Yes & Yes \\
\hline Observations & 356 & 563 \\
\hline$\%$ classified correctly & 74.44 & 79.75 \\
\hline McFadden $\mathrm{R}^{2}$ & 13.54 & 17.54 \\
\hline Log-ratio & $88.22 * * *$ & $133.96 * * *$ \\
\hline
\end{tabular}

*** Significant at the $1 \%$ level ** Significant at the 5\% level * Significant at the $10 \%$ level 


\section{Table 7}

\section{OLS regression test of differences in target shareholder abnormal returns between foreign bidders and Australian bidders}

The dependent variable is the target firm BHAR measured from 60 days prior to the takeover announcement until 30 days after. The main test variable (OVERSEAS) denotes takeovers where the bidder is located outside Australia. The other independent variables are target firm: free cash flow $(F C F)$, sales growth in the two years prior to the takeover (SALESGR), director ownership $(D I R O W N)$ capitalised research as a percentage of total assets (RESEARCH), size measured using the natural logarithm of market capitalisation (SIZE), debt-to-equity ratio $(L E V)$, market-to-book ratio $(M K T B K)$ return on equity ratio $(R O E)$ and a dummy variable indicating if the target firm is in the resources sector (RESOURCE). The model also includes dummy variables indicating: a competing takeover exists for the target firm (COMPBID), whether the consideration offered is entirely cash (CASHPAYT) and whether the initial recommendation of the target board is acceptance of the takeover (FRIENDLY). The model also includes the relative value of the Australian dollar over the sample period (EXCHRATE) and the ownership interest of the bidder at the time the takeover is announced (TOEHOLD). Interaction variables between OVERSEAS and RESEARCH (RES*OSEAS) and OVERSEAS and EXCHRATE $\left(E X C H^{*} O S E A S\right)$ are also included. Year indicator variables are also included in the model but results are not reported.

\begin{tabular}{lcc}
\hline & Cash only & All payt types \\
& $(1)$ & $(2)$ \\
\hline Intercept & 0.4098 & 0.1044 \\
OVERSEAS & $(2.46)^{* *}$ & $(0.69)$ \\
& 0.0826 & 0.0181 \\
FCF & $(1.77)^{*}$ & $(0.46)$ \\
& 0.1943 & 0.1079 \\
SALESGR & $(2.59)^{* * *}$ & $(1.33)$ \\
& -0.0001 & -0.0033 \\
DIROWN & $(-0.11)$ & $(-1.29)$ \\
& 0.0152 & -0.01630 \\
COMPBID & $(0.16)$ & $(-0.17)$ \\
& 0.0326 & 0.0750 \\
SIZE & $(0.77)$ & $(1.86)^{* *}$ \\
& -0.0034 & -0.0079 \\
LEV & $(-0.39)$ & $(-0.10)$ \\
MKTBK & 0.0001 & -0.0049 \\
& $(0.10)$ & $(-2.09)^{* *}$ \\
ROE & 0.0001 & 0.0009 \\
TOEHOLD & $(0.94)$ & $(0.85)$ \\
& -0.0203 & 0.0014 \\
FRIENDLY & $(-8.88)^{* * *}$ & $(0.49)$ \\
& -0.0195 & -0.0202 \\
RESOURCE & $(-0.86)$ & $(-0.75)$ \\
RESEARCH & 0.0245 & 0.0485 \\
EXCHRATE & $(0.62)$ & $(1.32)$ \\
RES*OSEAS & 0.1157 & 0.1489 \\
& $(2.37)^{* *}$ & $(3.52)^{* * *}$ \\
& -0.3206 & -0.3929 \\
& $(-1.06)$ & $(-1.15)$ \\
& -2.5865 & -2.2071 \\
& $(-3.28)^{* * *}$ & $(-3.16)^{* * *}$ \\
& 0.4435 & 0.5300 \\
& $(5.74)^{* * *}$ & $(4.81)^{* * *}$ \\
& &
\end{tabular}




\begin{tabular}{lcc} 
EXCH*OSEAS & 0.0441 & -0.1532 \\
& $(0.17)$ & $(0.62)$ \\
CASHPAYT & - & 0.1327 \\
& & $(3.48)^{* * *}$ \\
YEAR & Yes & Yes \\
Observations & 356 & 563 \\
Adjusted $\mathrm{R}^{2}$ & 10.02 & 7.31 \\
F-stat & $2.46^{* * *}$ & $2.58^{* * *}$ \\
\hline
\end{tabular}

*** Significant at the $1 \%$ level ** Significant at the 5\% level * Significant at the $10 \%$ level 


\section{Table 8}

\section{Logit model testing for differences in takeover characteristics between foreign bidders and Australian bidders}

This table presents the results of estimating three logit regression models. In column (1) the dependent variable is an indicator variable denoting takeovers where there are competing bidders. In column (2) the dependent variable is an indicator variable denoting takeovers where the bidder revises the offer price. In column (3) the dependent variable is an indicator variable denoting successful takeovers. The main test variable (OVERSEAS) denotes takeovers where the bidder is located outside Australia. Other independent variables are target firm: free cash flow $(F C F)$, sales growth in the two years prior to the takeover (SALESGR), director ownership (DIROWN) capitalised research as a percentage of total assets $(R E S E A R C H)$, size measured using the natural logarithm of market capitalisation $(S I Z E)$, debt-to-equity ratio $(L E V)$, market-to-book ratio $(M K T B K)$ return on equity ratio $(R O E)$ and a dummy variable indicating if the target firm is in the resources sector (RESOURCE). Dummy variables in the model indicate: a competing takeover exists for the target firm (COMPBID), and whether the initial recommendation of the target board is acceptance of the takeover (FRIENDLY). The models also include the ownership interest of the bidder at the time the takeover is announced (TOEHOLD) and the target firm BHAR measured from 60 days prior to the takeover announcement until 30 days after (BHAR).

\begin{tabular}{|c|c|c|c|}
\hline & $\begin{array}{l}\text { Competing } \\
\text { bidders } \\
(1) \\
\end{array}$ & $\begin{array}{c}\text { Offer revision } \\
(2) \\
\end{array}$ & $\begin{array}{c}\text { Outcome } \\
(3) \\
\end{array}$ \\
\hline Intercept & $\begin{array}{c}-0.7114 \\
(-0.53)\end{array}$ & $\begin{array}{c}-1.3768 \\
(-1.12)\end{array}$ & $\begin{array}{c}-2.1649 \\
(-1.65)\end{array}$ \\
\hline OVERSEAS & $\begin{array}{c}0.2101 \\
(0.72)\end{array}$ & $\begin{array}{l}-0.3231 \\
(-1.15)\end{array}$ & $\begin{array}{c}0.0055 \\
(0.02)\end{array}$ \\
\hline$B H A R$ & $\begin{array}{c}0.3166 \\
(0.87)\end{array}$ & $\begin{array}{c}0.3455 \\
(0.99)\end{array}$ & $\begin{array}{c}0.3872 \\
(0.92)\end{array}$ \\
\hline$F C F$ & $\begin{array}{l}1.2045 \\
(1.81)^{*}\end{array}$ & $\begin{array}{c}1.2910 \\
(2.08)^{* *}\end{array}$ & $\begin{array}{c}0.0408 \\
(0.07)\end{array}$ \\
\hline SALESGR & $\begin{array}{c}-0.0256 \\
(-0.68)\end{array}$ & $\begin{array}{c}0.0042 \\
(0.43)\end{array}$ & $\begin{array}{c}-0.0062 \\
(-0.62)\end{array}$ \\
\hline DIROWN & $\begin{array}{c}-3.7013 \\
(-2.96) * * *\end{array}$ & $\begin{array}{l}-1.8727 \\
(-2.07)^{* *}\end{array}$ & $\begin{array}{c}0.3566 \\
(0.33)\end{array}$ \\
\hline COMPBID & - & $\begin{array}{l}0.5032 \\
(1.83)^{*}\end{array}$ & $\begin{array}{c}-1.7075 \\
(-5.02) * * *\end{array}$ \\
\hline SIZE & $\begin{array}{c}0.0210 \\
(0.29)\end{array}$ & $\begin{array}{c}0.0727 \\
(1.09)\end{array}$ & $\begin{array}{c}0.0741 \\
(1.03)\end{array}$ \\
\hline$L E V$ & $\begin{array}{l}-0.0201 \\
(-0.63)\end{array}$ & $\begin{array}{c}0.0176 \\
(0.84)\end{array}$ & $\begin{array}{c}0.0826 \\
(0.76)\end{array}$ \\
\hline$M K T B K$ & $\begin{array}{c}0.0013 \\
(0.58)\end{array}$ & $\begin{array}{c}0.0016 \\
(0.84)\end{array}$ & $\begin{array}{c}-0.0004 \\
(-0.79)\end{array}$ \\
\hline$R O E$ & $\begin{array}{c}-0.8578 \\
(-2.23)^{* *}\end{array}$ & $\begin{array}{c}-0.0902 \\
(-0.48)\end{array}$ & $\begin{array}{c}-0.0732 \\
(-1.13)\end{array}$ \\
\hline TOEHOLD & $\begin{array}{c}-3.1579 \\
(-3.70) * * *\end{array}$ & $\begin{array}{c}-0.3874 \\
(-0.86)\end{array}$ & $\begin{array}{c}3.8428 \\
(3.42)^{* * *}\end{array}$ \\
\hline FRIENDLY & $\begin{array}{c}-0.0363 \\
(-0.13)\end{array}$ & $\begin{array}{c}-0.9617 \\
(-3.84)^{* * *}\end{array}$ & $\begin{array}{c}2.2922 \\
(6.80)^{* * * *}\end{array}$ \\
\hline RESOURCE & $\begin{array}{c}0.2278 \\
(0.72)\end{array}$ & $\begin{array}{c}0.2411 \\
(0.81)\end{array}$ & $\begin{array}{c}-0.3576 \\
(-1.01)\end{array}$ \\
\hline RESEARCH & $\begin{array}{c}-1.5394 \\
(-0.59)\end{array}$ & $\begin{array}{l}1.3904 \\
(0.74)\end{array}$ & $\begin{array}{c}-0.6212 \\
(-0.27)\end{array}$ \\
\hline
\end{tabular}


REVISION

0.9836

356

356

$(2.99)^{* * *}$

$\%$ classified correctly

77.53

68.82

356

McFadden $\mathrm{R}^{2}$

10.25

7.45

82.02

Log-ratio

$55.08 * * *$

$51.07 * * *$

28.74

$137.64 * * *$

*** Significant at the $1 \%$ level ** Significant at the 5\% level * Significant at the $10 \%$ level 


\section{Table 9}

\section{Comparison of bidder announcement returns by domicile}

This table presents abnormal returns around the takeover announcement for firms bidding for Australian listed targets. A $t$-test of differences in means between foreign and Australian bids is presented. A $t$-test of whether the abnormal returns are statistically different from zero is also presented.

\begin{tabular}{lccc}
\hline & $\begin{array}{c}\text { Australian } \\
\text { bidders }\end{array}$ & $\begin{array}{c}\text { Foreign } \\
\text { bidders }\end{array}$ & $\begin{array}{c}\text { Test of difference } \\
\text { Australian vs } \\
\text { Foreign }\end{array}$ \\
\hline $\begin{array}{l}\text { Panel A: All takeovers } \\
(-1,+1)\end{array}$ & 0.12 & 0.40 & -0.21 \\
$(-10,+10)$ & $-1.92 * *$ & -0.02 & -1.14 \\
Observations & 315 & 104 & \\
\hline Panel B: Cash takeovers & & & \\
$(-1,+1)$ & 0.46 & 0.40 & 0.04 \\
$(-10,+10)$ & $-1.63 * *$ & 0.16 & -1.07 \\
Observations & 138 & 102 & \\
\hline
\end{tabular}

*** Significant at the $1 \%$ level ** Significant at the 5\% level * Significant at the $10 \%$ level 